DOI: https://doi.org/10.18371/fp.3(35).2019.190171

УДК: 332.1:352.071

\title{
СУЧАНИЙ СТАН, ЮРИДИЧНІ АСПЕКТИ ДІЯЛЬНОСТІ, ПРОБЛЕМИ РОЗВИТКУ ОБ'ЄДНАНИХ ТЕРИТОРІАЛЬНИХ ГРОМАД ТА ШЛЯХИ ЇХ ВИРІШЕННЯ
}

\author{
ПЕТЬКО Володимир Миколайович \\ старший викладач публічного управління \\ та адміністрування \\ ДВНЗ «Херсонський держсавний аграрний університет» \\ kaf_public@ksau.kherson.ua
}

\section{ЯРМОЛЕНКО Віталіна Вікторівна}

асистент кафедри економіки та фінансів

ДВНЗ «Херсонський держсавний аграрний університет»

vitalina.yarmolenko2016@gmail.com

\begin{abstract}
Анотація. B статті проаналізовано динаміку утворення об'єднаних територіальних громад, в умовах орієнтації національної економіки на зарубіжний досвід. Доведено, що саме об'єднані територіальні громади є фундаментом формування нової політики сталого розвитку територій Украӥни. Після проведення дослідження було встановлено, щзо за останні роки було прийнято деякі законодавчі та нормативні акти, які регулюють проблемні питання процесу формування та розвитку ефективних, потужних територіальних громад. Розглянуто проблеми розвитку об'єднаних територіальних громад та визначити шляхи їх вирішення. Вивчено досвід пошуку та залучення коштів для сочіально-економічного розвитку. Обтрунтовано заходи, які дочільно проводити громадам з метою підвищення інвестиційної привабливості території.
\end{abstract}

Ключові слова: об'єднані територіальні громади, децентралізація, формування, ресурсне забезпечення.
Аннотация. $B$ cтатье проанализирована динамика образования объединенных территориальных общин, в условиях ориентации национальной экономики на зарубежный опыт. Доказано, что именно объединенные территориальные общины является фундаментом формирования новой политики устойчивого развития территории Украины. После проведения исследования было установлено, что за последние годы были приняты некоторые законодательные и нормативные акты, регулирующие проблемные вопросы прочесса формирования $u$ развития эффрективных, мощзных территориальных общин. Рассмотрены проблемы развития объединенных территориальных обшин и определить пути их решения. Изучен опыт поиска и привлечения средств для сочиально-экономического развития. Обоснованы мероприятия, которые целесообразно проводить общинам с целью повышения инвестиционной привлекательности территории.

Ключевые слова: объединенные территориальные общины, децентрализачия, формирование, ресурсные обеспечения. 
Постановка проблеми. Розбудова соціальної, правової, демократичної держави в умовах децентралізації та проведення конституційної реформи в Україні, зумовлює відповідні процеси розбудови інституту місцевого самоврядування, первинним суб'єктом якого виступає територіальна громада. На сьогодні функціонування національної економіки орієнтується на європейські засади зростання, проводиться ефективна соціально орієнтована державна політика. Одна із головних засад розвитку України $є$ проведення реформи територіальної організації влади, а саме децентралізації влади на місцях. Наявні результати дають можливість стверджувати, що спостерігається підвищення зацікавленості органів місцевого самоврядування в збільшенні надходжень до місцевих бюджетів, у пошуку резервів ï наповнення, покращення ефективності адміністрування податків і зборів. Об'єднані територіальні громади демонструють динамічні темпи приросту власних доходів.

Аналіз останніх досліджень та публікацій. Дослідженням проблематики місцевого самоврядування, у тому числі з'ясуванні ролі територіальної громади як первинного суб'єкта у сфері місцевого розвитку, присвячено праці М. Баймуратова, О. Батанова, В. Бесчастного, В. Борденюка, I. Бутка, П. Ворони, П. Гураля, С. Газаряна, С. Глухачова, Р. Давидова, I. Дегтярьової, I. Дробота, І. Дробуша, В. Кампо, Н. Камінської, А. Коваленка, М. Корнієнка, В. Кравченка, В. Куйбіди, Ю. Куца, І. Лопушинського, О. Лиски, В. Мамонової, Ю. Молодожена, М. Орзіха, Г. Падалки, О. Па- стернака, Р. Плюща, В. Погорілка, М. Пухтинського, О. Слобожана, Ю. Тодики, О. Фрицького, В. Шаповала та інших.

Метою даної статті $€$ комплексний розгляд особливостей становлення i розвитку об'єднаних територіальних громад в умовах децентралізації, аналіз проблем розвитку ОТГ та розробка шляхів їх подолання.

Виклад основного матеріалу. Реформа децентралізації почалася в Україні в 2014 році. Цьому передувало ухвалення Концепції реформи місцевого самоврядування та територіальної організації влади [1] і низки інноваційних законів, зокрема: «Про співробітництво територіальних громад» [2],«Про добровільне об’єднання територіальних громад» [3], змін до Бюджетного та Податкового кодексів стосовно фінансової децентралізації. Добровільним об'єднанням членів ОТГ передбачається отримання можливості розпоряджатися матеріальними та нематеріальними ресурсами, якими володіє громада, зокрема трудовими, фінансовими, матеріальнотехнічними, природними, інформаційними, маркетинговими, інноваційними, управлінськими тощо. Отримання самостійності у прийнятті рішень щодо формування й використання ресурсного потенціалу ОТГ є потужною передумовою їх активного поширення, підтвердженням чому $\epsilon$ відповідні індикатори оцінки динаміки їх формування (табл. 1, рис. 1). Цей процес дозволив формувати, відповідно до положень Європейської хартії місцевого самоврядування, значний дієвий і спроможний інститут місцевого са- 
моврядування на базовому рівні - об’єднані територіальні громади.

Таблиця 1

Динаміка формування об’єднаних територіальних громад в Україні

\begin{tabular}{|c|c|c|c|c|c|}
\hline \multirow{2}{*}{ Індикатор } & \multicolumn{4}{|c|}{ Рік } & \multirow{2}{*}{$\begin{array}{l}2018 \text { р. до } \\
2015 \text { р., \% }\end{array}$} \\
\hline & 2015 & 2016 & 2017 & 2018 & \\
\hline Кількість ОТГ, од. & 159 & 366 & 665 & 798 & 501,89 \\
\hline $\begin{array}{l}\text { Кількість жителів ОТГ, } \\
\text { млн осіб }\end{array}$ & 1,4 & 3,1 & 5,6 & 6,3 & 450 \\
\hline Площа ОТГ, тис. км ${ }^{2}$ & 36,5 & 84,2 & 164,1 & 179,2 & 490,96 \\
\hline $\begin{array}{l}\text { Кількість територіаль- } \\
\text { них громад, що утвори- } \\
\text { ли об'єднані тери- } \\
\text { торіальні громади, од. }\end{array}$ & 804 & 1747 & 3124 & 3378 & 420,15 \\
\hline $\begin{array}{l}\text { Кількість необ’єднаних } \\
\text { територіальних громад, } \\
\text { од. }\end{array}$ & 10411 & 9468 & 8091 & 7837 & 75,28 \\
\hline
\end{tabular}

Відтак, протягом 2015-2018 pр. України), що у 4,9 рази більше, ніж у кількість ОТГ зросла у 4,6 рази до рів- 2015 р. Протягом досліджуваного ня 798 у 490 районах. Кількість жи- періоду кількість територіальних гротелів ОТГ становить у 2018 р. 6,3 млн мад, що утворили об'єднані териосіб (14,9\% від загальної чисельності торіальні громади, зросла у 4,2 рази до населення України), що у 4,5 рази 3378 од. у 2018 р. (30,1\% від загальної більше, ніж у 2015 р. Щодо площі кількості рад базового рівня станом на ОТГ, то у 2018 р. вона становить 179,2 01.01.2015 р.).

тис. км2 (31,1 \% від загальної площі

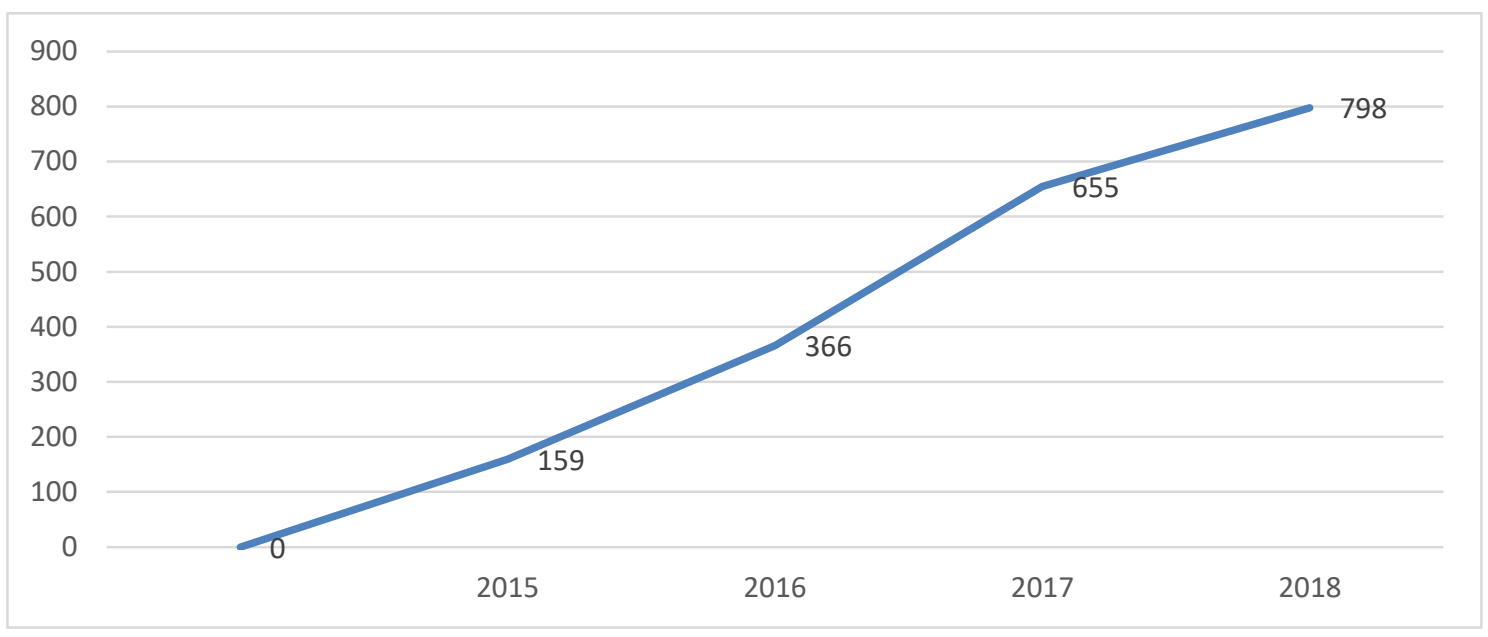

Рис. 1. Кількість об’єднаних територіальних громад, од.

Разом 3 тим, зберігається значна веденні процесу об'єднання теринерівномірність між регіонами у про- торіальних громад (рис. 2). 


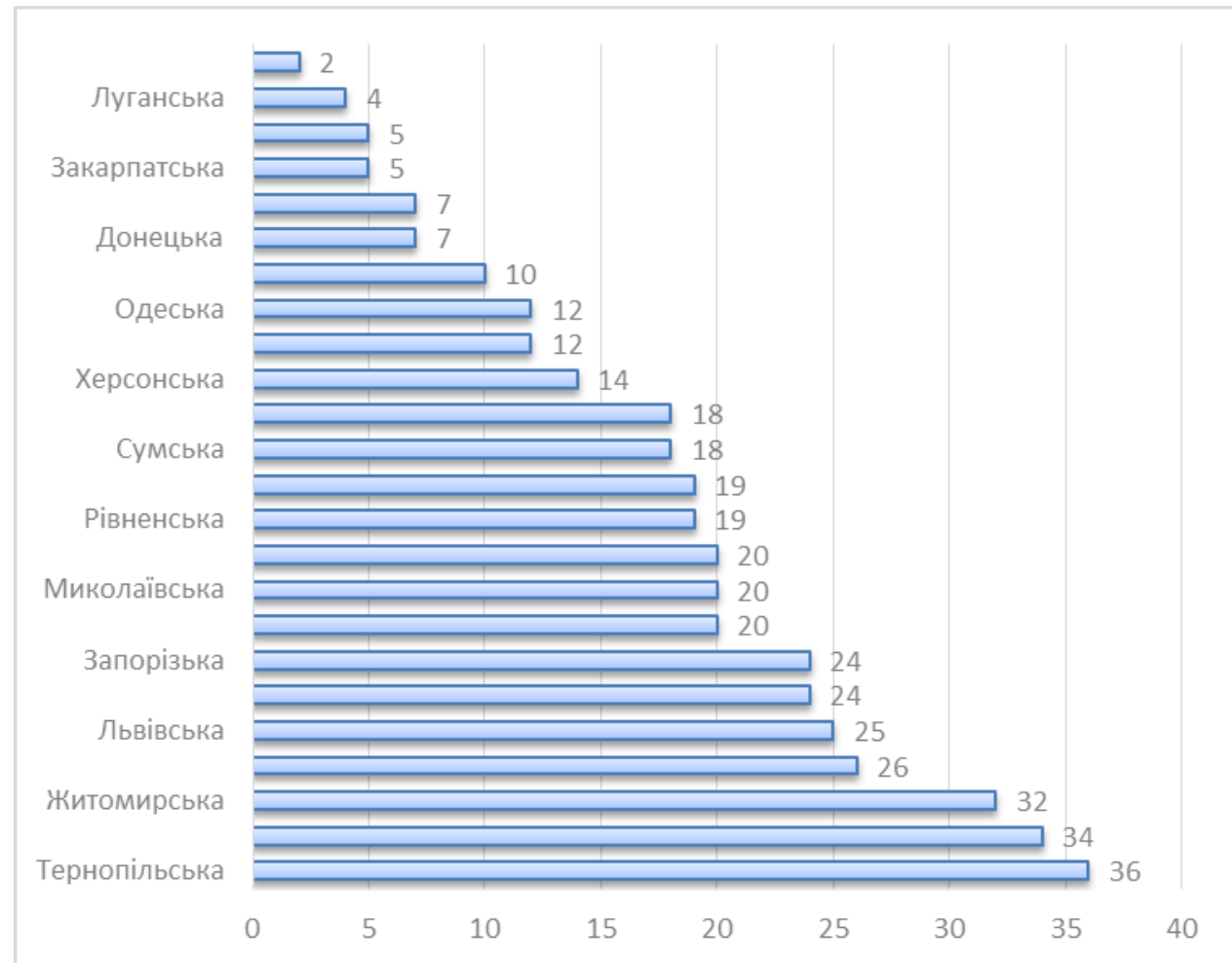

Рис. 2. Кількість створених об’єднаних територіальних громад в регіонах України в 2017 р., од.

Найбільшу кількість ОТГ створено у Тернопільській (36 ОТГ), Дніпропетровській (34 ОТГ), Житомирській (32 ОТГ), Хмельницькій (26 ОТГ), Львівській (25 ОТГ), Вінницькій та Запорізькій (по 24 ОТГ) областях. Сумарна частка перших трьох із зазначених регіонів становить чверть $(24,6 \%)$ всіх ОТГ країни. Водночас окремі регіони суттєво відстають у процесі формування ОТГ, серед них Київська (2 ОТГ), Харківська та Закарпатська (по 5 ОТГ) області.

Значна відмінність між регіонами за динамікою формування об'єднаних територіальних громад, запровадження механізму співробітництва громад передусім обумовлена різним ставленням місцевих державних адміністрацій та органів місцевого самоврядування в регіонах до запровадження реформи децентралізації.
Досвід закордонних країн дозволяє стверджувати, що під час визначення заходів щодо децентралізації необхідне врахування принципу субсидіарності, який значною мірою характеризую та розкриває зміст цього процесу на сучасному етапі розвитку суспільства. Цей принцип створює підгрунтя для децентралізації повноважень публічної влади, оскільки передбачає передачу повноважень на ухвалення рішень із центрального на нижчі організаційні рівні. Реалізація зазначеного курсу має стати одним із вимірів державної влади та місцевого самоврядування України відповідно до стандартів і принципів країн розвинутої демократії [4, с. 76-78].

Новостворені об'єднані територіальні громади беруть на себе всю відповідальність за всі сфері життєдіяльності громади на своїй тери- 
торії. Ефективність реалізації поставлених перед ОТГ задач $є$ основним показником успішності даного об’єднання та реформи загалом.

Однак в умовах нинішньої політичної нестабільної ситуації в Україні, економічної та соціальної кризи, зовнішньої агресії децентралізація, на думку О. Скрипнюка [5, c. 24], може призвести до поглиблення наявних та появи нових негативних тенденцій у розвитку держави й суспільства.

Він вважає, що це варто передбачити й бути готовими до таких викликів:

- поглиблення регіональних ідентичностей серед населення, сепаратистських настроїв в окремих регіонах;

- посилення контролю за видатками та їхніми джерелами, обсягами сваволі чиновників та місцевих еліт, зростання незадоволення населення регіонів владою, зокрема центральною, яка демонструватиме неспроможність захистити інтереси та права регіональних громад;

- небезпека відцентрових тенденцій через вкрай низький рівень відповідальності держави перед адміністративно-територіальними суб'єктами.

Не дивлячись на те, що з прийняттям Закону України «Про добровільне об'єднання територіальних громад» [3] почався динамічний процес об'єднання в територіальні громади по всій території України. В той же час при формуванні громад почала виникати низка проблем, серед них найактуальнішими $\epsilon$ такі:
1) проблема сприйняття реформи мешканцями об'єднаних територій. Через незрозумілу на самому початку інформаційну політику та відсутність роз'яснень щодо процесів децентралізації реформі опираються як жителі, так i районні державні адміністрації та місцеві ради. Пояснюється такий опір в основному тим, що будуть втрачені робочі місця та повноваження, адже реформа передбачає переформатування органів місцевої влади та передачу повноважень громадам [6, с. 32];

2) ще однією нагальної проблемою впровадження децентралізації $\epsilon$ неузгодженість повноважень між органами виконавчої влади, органами місцевого самоврядування, органами управління в ОТГ, райрадами та райдержадміністраціями.

Проблема фінансової децентралізації пов'язана зі збільшенням кількості ОТГ, особливо у 2016-2017 pp. Це не завжди супроводжується збільшенням субвенцій від держави на розвиток інфраструктури та суттєво зменшує мотивацію громад до об'єднання, особливо тих, які є «багатшими» від громад, що до них приєднуються [6, с. 33-34].

Взагалі, на думку Н. Мацедонської [7, с. 90-92], фінансова децентралізація сьогодні потребує суттєвого доопрацювання, оскільки нині міжбюджетне фінансування в країні має низку проблем, а саме:

- бюджетна децентралізація передбачає більш широкий спектр повноважень місцевих органів влади, ніж той, що зараз $є$ в центральних органів влади України; 
- неузгодженість між забов'язаннями фінансування;

- місцеві органи влади не мають важелів і стимулів щодо збільшення надходжень до бюджетів, а також не мають права самостійно, прозоро, у повному обсязі здійснювати управління власними ресурсами;

- протягом тривалого часу система міжбюджетного фінансування розвивалася непередбачувано. Не було науково-методичних до розрахунків, що впливало на управління бюджетами в напрямі планування та прогнозування;

- недосконала інституційна та правова база міжбюджетного фінансування не дає поштовху до розвитку інфраструктури регіонів і не сприяе забезпеченню суспільних благ.

Кінцевим результатом децентралізації має стати створення нової системи місцевих бюджетів та міжбюджетних відносин, в основі якої повинна бути інституційна симетрія, що передбачає поєднання та взаємозв'язок економічних суб'єктів, які користуються суспільними благами, сплачують податки (несуть тягар витрат), і тих, хто самостійно ухвалює рішення про їх надання (місцеві органи влади);

3) також серйозною проблемою сьогодні $\epsilon$ суттєвий брак якісних кадрів, низька кваліфікація службовців органів місцевого самоврядування. Це призводить до неготовності кадрів сприймати інновації, розробляти й ухвалювати ефективні управлінські рішення, до неефективного використання фінансових ресурсі та неможливості ефективно освоїти субвенції. Нездатність та небажання місцевих чиновників до сприйняття нових технологій розроблення управлінських рішень здебільшого пов'язані 3 недостатньою поінформованістю про можливості підвищення кваліфікації та програми, що зараз популярні i пропонуються закордонними та вітчизняними партнерами. У зв'язку 3 цим важливо залучати депутатів та чиновників ОТГ до таких програм [6, c. 35-36];

4) особливої увагу потребує проблема контролю держави за діяльністю місцевого самоврядування. В умовах бюджетної децентралізації наявна потреба в якісному контролі за здійсненням планування та використанням бюджетних коштів як із боку держави, так і з боку громадськості [6, c. 37].

У ст. 8 Свропейської хартії місцевого самоврядування передбачено принципи адміністративного нагляду за діяльністю органів місцевого самоврядування, але це зроблено так, щоб між наглядом і автономністю місцевих органів влади був максимальний баланс [8].

«Держава забов'язана контролювати законність рішень громад. Це - європейська практика. I ця система має бути максимально зрозуміла. Краще, коли загальний нагляд здійснюе один орган, а не десять чи двадцяти. Коли учасників багато i нема єдиної системи, отримуємо хаос у державних інституціях, безпорадність i незахищеність місцевого самоврядування», - сказав під час обговорення професор Страсбурзького університету, експерт Ради Європи Робер Герцог [9];

5) основною проблемою, яка сьогодні хвилює членів сільських та 
селищних громад, оскільки об'єднання територіальних громад, на наш погляд, покликане покращити, в першу чергу, становище саме таких громад та підвищити рівень добробуту ï членів, є земельна проблема. Членів громади турбує чи залишиться за ними їхня земля, чи зможуть вони організовувати власні кооперативні та фермерські господарства, чи земля стане загальною власністю об'єднаної громади? Відкритим залишається і питання щодо землі, яка знаходиться за межами сіл. Раніше функції з управління ними передавалися районним державним адміністраціям, зараз 3 об'єднанням громад функції з управління ними можуть бути покладені на органи місцевого самоврядування об’єднаної територіальної громади [6, c. 39-40].

Відомо, що основними фінансовими інструментами, за допомогою яких використовуються бюджетні кошти громади, є місцеві цільові програми, муніципальні проекти соціальноекономічного розвитку в рамках реалізації регіональних стратегій, угоди про міжмуніципальне співробітництво. Проте бюджетні кошти не можуть бути єдиним фінансовим ресурсом місцевого розвитку, що вимагає пошуку інших джерел фінансування.

Об’єднана громада одразу отримує більше можливостей для підвищення рівня конкурентоспроможності завдяки збільшенню ресурсів, об'єднанню зусиль, розширенню повноважень, виникненню нових перспектив розвитку. Разом із тим залишаються невирішеними чимало питань правового забезпечення формування функціонування інституту комунальної власності об’єднаної громади (перш за все - землі), що вимагає їхнього врегулювання на законодавчому рівні.

Необхідно активізувати широкий суспільний діалог 3 громадою не лише на етапі підготовки до об'єднання, а й після нього - 3 метою залучення громадських організацій, науковоосвітніх установ до співпраці під час формування різноманітних проектів і програм розвитку.

Висновки. Таким чином, сьогодні однією 3 найуспішніших реформ в Україні по праву вважають реформу децентралізації. У найпростішому розумінні, децентралізація влади означає передачу політичних, адміністративних та/або фінансових повноважень підрозділам середнього та/або нижчих рівнів державної ієрархії. Однак найважливішою складовою у процесі децентралізації є надання саме фінансових (бюджетних) повноважень ОТГ, тобто проведення бюджетної децентралізації, що дозволить створити умови для забезпечення їх сталого економічного зростання та розвитку, високої продуктивності наявних ресурсів та добробуту населення.

Не дивлячись на те, що з прийняттям Закону України «Про добровільне об'єднання територіальних громад» почався динамічний процес об'єднання в територіальні громади по всій території України. В той же час при формуванні громад почала виникати низка проблем, серед них найактуальнішими $€$ такі:

- проблема сприйняття реформи мешканцями об'єднаних територій; 
- проблема неузгодженості повноважень між органами виконавчої влади, органами місцевого самоврядування, органами управління в ОТГ, районними радами та районними держадміністраціями;

- суттєвий брак якісних кадрів, низька кваліфікація службовців органів місцевого самоврядування;

- особливої увагу потребує проблема контролю держави за діяльністю місцевого самоврядування;

- основною проблемою, яка сьогодні хвилює членів сільських та селищних громад $\epsilon$ земельна проблема.

Для вирішення зазначених проблем необхідно забезпечити:

1) перегляд та формування перспективного плану об'єднання територіальних громад 3 максимальним урахуванням географічної, культурної, етнічної та іншої специфіки громад;

2) інформаційно-роз'яснювальний супровід процесу об'єднання територіальних громад;

3) проведення навчальних семінарів для працівників органів місцевого самоврядування та громадськості щодо різних аспектів реформи. При цьому самі громади, органи самоврядування, громадські об'єднання та активісти повинні не чекати запрошення, а активно включатися у процес рефор- мування органів самоврядування на місцях.

Наостанок необхідно відмітити, що в Україні постійно посилаються на результати Польщі в реформуванні місцевого самоврядування, не звертаючи уваги, що Польща п'ять років готувалася до цього кроку, а саме: зробили нормально працюючі електронні сервіси, якісне інтернетпокриття, якісні дороги, щоб можна було швидко дістатися до адміністративних центрів, а вже після того почали об'єднувати громади. В Україні поки що все робиться 3 точністю до навпаки.

Отже, для України важливим пріоритетом становлення як потужної соціально орієнтованої європейської держави $є$ розвиток системи місцевого самоврядування. Реформування даної системи у напрямі децентралізації влади на місцях складно досягти ефективного розвитку територіальних громад, а відтак - забезпечити високий рівень якості життя населення. Зміна усталеної парадигми управління державою у напрямі формування місцевої демократичної влади за рахунок удосконалення системи управління на місцях, розширення повноважень органів місцевого самоврядування, слід розглядати сьогодні необхідною умовою активізації процесів сталого розвитку України.

\section{Список використаної літератури}

1. Про схвалення Концепції реформи місцевого самоврядування та територіальної організації влади: Розпорядження Кабінету Міністрів України від 1 квітня 2014 p. № 333-р. Офіційний веб-портал Верховної Ради України. URL: https://zakon.rada.gov.ua/laws/show/333-2014-p. 
2. Про співробітництво територіальних громад: Закон України від 24 липня 2014 року № 1508-VII. Офіційний Веб-сайт Верховної Ради України. URL: https://zakon.rada.gov.ua/laws/show/1508-18.

3. Про добровільне об'єднання територіальних громад: Закон України від 5 лютого 2015 року № 157-VIII. Офіційний Веб-сайт Верховної Ради України. URL: https://zakon.rada.gov.ua/laws/show/157-19/ed20190101.

4. Василенко Л. Децентралізація та реформа місцевого самоврядування. Підприємництво, господарство і право. 2017. № 3. С. 76-80.

5. Скрипнюк О. Децентралізація влади як чинник забезпечення стабільності конституційного ладу: теорія й практика. Віче: громадсько-політичний $i$ теоретичний журнал. 2015. № 12. С. 22-24.

6. Пухтинський М. Проблеми розвитку об'єднаних територіальних громад. Актуальні проблеми місиевого самоврядування : Наукові записки НаУКМА. К. 2016. Т. 149. С. 32-40.

7. Мацедонська Н. Децентралізація в Україні та основні шляхи її впровадження. Економіка і суспільство. 2017. № 8. С. 90-94.

8. Свропейська хартія місцевого самоврядування від 15 жовтня 2018 року. Офіційний Веб-сайт Верховної Ради України URL: https://zakon.rada.gov.ua/laws/show/994_036.

9. Герцог Р. Жодних нових зобов'язань i жодних обмежень. URL: https://decentralization.gov.ua/news/9504. 